\title{
Comparing Disease Predictors and Fungicide Programs for Late Blight Management in Celery
}

\author{
R. S. Bounds, Former Graduate Assistant, and M. K. Hausbeck, Professor, Department of Plant Pathology, Michi- \\ gan State University, East Lansing 48824-1311
}

\begin{abstract}
Bounds, R. S., and Hausbeck, M. K. 2007. Comparing disease predictors and fungicide programs for late blight management in celery. Plant Dis. 91:532-538.

Late blight, incited by the fungus Septoria apiicola, is the most important foliar disease of celery in Michigan and results in necrotic lesions on leaves and petioles that can reduce yield up to $80 \%$. Most celery growers apply the fungicide chlorothalonil as frequently as every 7 days to protect the crop; however, some of these applications may not be needed when environmental conditions do not favor disease development. The purpose of this study was to evaluate disease predictors using a standard (chlorothalonil) and a reduced-risk (azoxystrobin alternated with chlorothalonil) fungicide program for managing late blight on 'Dutchess' celery in 2003 to 2005. Fungicides were initiated 1 week after transplanting and reapplied every 7 days or according to the Septoria, Cercospora, or TOM-CAST predictors. The TOM-CAST predictor was tested using 10, 15, and 20 disease severity values (DSV) as thresholds for fungicide application. In each year of this study, timing sprays according to the TOM-CAST 10-DSV predictor resulted in disease control comparable with the 7-day interval, but required up to five fewer sprays and reduced fungicide costs up to $\$ 215 / \mathrm{ha}$. The Septoria, Cercospora, and TOM-CAST 15-DSV predictors often provided control similar to the 7-day interval, but these predictors were somewhat inconsistent compared with TOM-CAST 10-DSV. The TOM-CAST 20-DSV predictor required the fewest number of sprays but unacceptable levels of disease resulted. The standard and reduced-risk fungicide programs frequently provided similar control; however, azoxystrobin alternated with chlorothalonil was more effective than chlorothalonil alone when disease pressure was high.
\end{abstract}

Late blight, incited by Septoria apiicola Speg., is an important foliar disease of celery (Apium graveolens L. var. dulce (Mill.) Pers.) in Michigan $(1,15,26)$ and California $(2,22)$. The disease also occurs in Florida (6) but has not been an annual problem in recent years (23). Late blight symptoms typically appear first on the older, outer leaves and are characterized by irregularly shaped, necrotic lesions (15) which sometimes are surrounded by a diffuse, chlorotic margin (16). The disease is easily distinguished from other common foliar diseases of celery in Michigan, such as early blight (incited by Cercospora apii) (25) and bacterial leaf spot (incited by Pseudomonas syringae pv. apii) (29), because black pycnidia are embedded in $S$. apiicola lesions (14). Conidial germination is highest in the presence of free moisture (48) and infection occurs when celery leaves remain wet for $\geq 12 \mathrm{~h}(24,30)$. Conidia are splash dispersed by rainfall or overhead irrigation (6) and are moved by mechanical means in conidia-laden water

Corresponding author: M. K. Hausbeck

E-mail: hausbec1@msu.edu

Accepted for publication 10 November 2006.

doi:10.1094/PDIS-91-5-0532

(C) 2007 The American Phytopathological Society droplets by farm laborers and machinery (28). Severely blighted tissues wither and senesce (15). Diseased petioles must be removed manually at harvest, a timeconsuming process which increases harvesting costs and reduces yields. Untreated plants can weigh 56 to $82 \%$ less after diseased petioles are removed $(11,41)$; these plants are not marketable because only a few small, healthy petioles remain.

Foliar fungicides are often the primary tool for control of late blight (27) and can be applied as frequently as every 7 days (8). The calendar-based management approach may result in excessive applications when environmental conditions do not favor disease development. Most growers use the protectant fungicide chlorothalonil, which is classified as a B2 carcinogen, to manage late blight because it is effective $(10,40,41)$ and relatively inexpensive. Azoxystrobin is a relatively new, reducedrisk fungicide labeled for use on celery that protects against $S$. apiicola $(11,20,44)$. Azoxystrobin has systemic and curative properties and must be alternated with fungicides that have a different mode of action to prevent or delay the occurrence of fungicide-resistant strains of plant pathogens (3). The use of chlorothalonil in alternation with azoxystrobin is typically recommended because both products effectively limit late blight and they have different modes of action. Including azoxystrobin in a spray program to manage late blight may displace some of the applications of the B2 carcinogen, chlorothalonil.

Applying fungicides only when environmental conditions are favorable for $S$. apiicola may reduce the overall number of applications needed for effective disease control, reducing pesticide inputs to the environment. Two disease predictors have been developed to manage foliar diseases of celery. Lacy (24) developed an S. apiicola model (hereafter referred to as the Septoria predictor) which requires measurements of leaf wetness duration. Berger $(4,5)$ developed a $C$. apii model (hereafter referred to as the Cercospora predictor) which requires measurements of relative humidity (RH) and temperature use in conjunction with a spore trap. Both disease predictors reduced the number of fungicide applications needed to obtain disease control compared with calendar-based application schedules $(5,24)$. A disease predictor that includes both leaf wetness duration and temperature may be appropriate for managing $S$. apiicola because both parameters are important for disease development (30).

The TOM-CAST disease predictor originally was developed to manage foliar diseases (incited by Alternaria solani and S. lycopersici) and anthracnose fruit rot (incited by Colletotrichum coccodes) on tomato (39). The system utilizes the duration of leaf wetness and average temperature during the wetness period to calculate a daily disease severity value (DSV). A fungicide is applied when the cumulative DSV reaches a predetermined threshold (39). Since its development for use on tomato, TOM-CAST has been validated for use in managing Cercospora carotae and A. dauci on carrot $(13,46)$ and Stemphylium vesicarium on asparagus (32).

Michigan celery growers are interested in reducing their reliance on the calendarbased fungicide regime and desire a late blight management strategy that lowers production costs while maximizing quality and yield (1). A preliminary study indicated that the TOM-CAST disease predictor may be appropriate for managing late blight of celery; however, only a single DSV threshold was tested (19). The objective of this study was to compare disease predictors using a grower standard and a reduced-risk fungicide program to manage late blight on celery. 


\section{MATERIALS AND METHODS}

Plot establishment and inoculation. The study was conducted at the Michigan State University Muck Soils Research Farm in Laingsburg, MI from 2003 to 2005. Seven- to eight-week old 'Dutchess' celery transplants were set $17.8 \mathrm{~cm}$ apart in rows spaced $0.8 \mathrm{~m}$ apart on 28 May 2003, 21 June 2004, and 25 May 2005 in Houghton muck soil, previously planted with potato (2003 and 2004) or carrot (2005). Each treatment plot consisted of one row $6.1 \mathrm{~m}$ long which included approximately 34 plants. Sections of inoculated buffer row $(0.8$ to $1.5 \mathrm{~m})$ bordered the ends of each plot, and two inoculated buffer rows separated adjacent treatment rows. In all, 13 treatments, which included 1 untreated control and 12 fungicide programs, were arranged in a randomized complete block design in four blocks. Weed, insects, and fertilization requirements were managed according to standard production practices $(8,54,55)$. Sprinkler irrigation was used to maintain the water requirements of the crop and to promote Septoria apiicola infection.

Inoculum was prepared and applied according to the procedures described by Lacy et al. (27). Dried celery leaves infected with $S$. apiicola were soaked in tap water for $10 \mathrm{~min}$, and the debris was removed by straining the spore suspension through two layers of cheesecloth. Spore concentration was determined using a hemacytometer, and the final spore suspension was adjusted to $1 \times 10^{6}$ conidia $/ \mathrm{ml}$ with water just prior to inoculation. Plots were sprinkler irrigated to wet the foliage for approximately $60 \mathrm{~min}$ prior to inoculation. Inoculum was applied at dusk with a hand-pump sprayer equipped with one hollow-cone or flat-fan nozzle delivering approximately 168 liters/ha. All buffer rows were inoculated (i.e., every plant except those in treatment plots); care was taken to avoid inoculating plants in treatment rows. This indirect inoculation approach was used to allow S. apiicola to spread under natural splash-dispersal conditions. Twelve or more hours of continuous leaf wetness were maintained by short intervals (10 to $15 \mathrm{~min}$ ) of sprinkler irrigation in the morning after each inoculation. All buffer rows were inoculated twice each season at 42 and 49 days after planting (DAP) (2003 and 2005) and 39 and 51 DAP (2004)

Disease predictors and fungicide programs. The Septoria predictor requires a fungicide application when $\geq 12 \mathrm{~h}$ of consecutive leaf wetness occurs if no fungicides were applied during the previous 7 days (24). The Cercospora predictor used in this study was similar to the program developed in Florida (4), but without the spore-trapping component. The sporetrapping component of the predictor was omitted in an effort to test the system in a manner growers or crop consultants could operate without requiring excessive time or expensive equipment. A fungicide spray was applied if all of the following criteria were met: (i) no fungicides were applied during the previous 7 days; (ii) $\geq 12 \mathrm{~h}$ of $\mathrm{RH} \geq 90 \%$ were recorded the previous day (0700 yesterday to 0600 today); (iii) mean temperature was 15 to $30^{\circ} \mathrm{C}$ during the previous day; and (iv) temperatures three days ago were $\geq 12^{\circ} \mathrm{C}$, or, if the temperature fell below $12^{\circ} \mathrm{C}$, the mean night temperature (2200 to 0700 ) on each of the two succeeding nights was $\geq 15^{\circ} \mathrm{C}$ with a mean $\mathrm{RH} \geq 95 \%$.

For each 24-h period (1100 to 1100), TOM-CAST used the hours of leaf wetness and the average temperature during the wetness periods to calculate a DSV, ranging from 0 to 4 , corresponding to environmental conditions unfavorable to highly favorable for disease development, respectively (39). Daily DSVs were summed and accumulated until a threshold value was reached, a fungicide spray was applied, and the DSV total was reset to zero. Unlike the Septoria or Cercospora predictors, the TOM-CAST program was not tested with a minimum fungicide reapplication interval because none was specified when the predictor was developed for tomato (39) or when the predictor was validated for use in asparagus (32) or carrot (13).

Hourly measurements of temperature and leaf wetness were obtained using a digital data recorder (WatchDog Leaf Wetness and Temperature Logger 3610TWD; Spectrum Technologies, Inc., Plainfield, IL) located in the upper $75 \%$ of the crop canopy in an unsprayed row at a $45^{\circ}$ angle facing north. A second digital data recorder (WatchDog Data Logger Model 450; Spectrum Technologies, Inc.) made hourly measurements of $\mathrm{RH}$, temperature, and rainfall and was located in the upper $75 \%$ of the crop canopy. A tipping-bucket rain gauge (model 3665R; Spectrum Technologies, Inc.) collected rainfall and sprinkler irrigation and was located $1.2 \mathrm{~m}$ above the soil surface. Data recorders were placed in the plots after transplanting and were set to record temperatures from 0 to $100^{\circ} \mathrm{C}$ and leaf wetness (i.e., wetness threshold set to 0) where applicable. Data were downloaded at least every other day to a laptop computer using a computer program (Specware 6.02; Spectrum Technologies, Inc.) equipped to calculate DSVs for the TOM-CAST predictor. Raw hourly data were examined to determine the number of hours of consecutive leaf wetness for the Septoria predictor. Similarly, raw hourly data were examined to determine the number of hours of $\mathrm{RH} \geq 90$ or $\geq 95 \%$ and to calculate average temperatures for the Cercospora predictor.

The reduced-risk fungicide azoxystrobin (Quadris 2.08F at $0.17 \mathrm{~kg}$ a.i./ha; Syngenta Crop Protection, Inc., Greensboro, NC) and the fungicide chlorothalonil (Bravo Ultrex 82.5WDG at $1.7 \mathrm{~kg}$ a.i./ha; Syn- genta Crop Protection, Inc.) were applied either in an alternating program (hereafter referred to as azoxystrobin/chlorothalonil), where azoxystrobin was applied at the initial application, or in a grower standard program, where chlorothalonil was applied exclusively. The 13 treatments included in this study were composed of an untreated control plus 12 fungicide treatments where both fungicide programs (azoxystrobin/ chlorothalonil and chlorothalonil) were tested with each of the six application programs: (i) 7-day interval, (ii) Septoria predictor, (iii) Cercospora predictor, (iv) TOM-CAST 10-DSV, (v) TOM-CAST 15DSV, and (vi) TOM-CAST 20-DSV. To allow for equal comparison among application programs, all fungicide treatments received an initial spray 1 week after transplanting. Applications were made with a $\mathrm{CO}_{2}$ backpack boom sprayer ( $\mathrm{R} \&$ D Sprayers, Opelousas, LA) equipped with three Teejet XR8003VS flat-fan nozzles (Spraying Systems Co., Wheaton, IL) spaced $45.7 \mathrm{~cm}$ apart, operating at a boom pressure of $359 \mathrm{kPa}$ and delivering 467.6 liters/ha. The cost of fungicides applied for each treatment was calculated by multiplying the number of applications by estimated costs of azoxystrobin (\$53/ha) or chlorothalonil (\$28/ha) per application.

Disease assessment. Weekly visual evaluations of leaf blight severity were conducted on 20 plants from the middle of each treatment plot using a celery leaf blight assessment key developed by Strandberg (unpublished). According to the key, plots were assigned values of 0,1 , $5,10,15,20,25,30,35,40,45$, or $50 \%$ leaf blight. The celery leaf blight assessment key was similar to the leaf blight assessment key developed for carrot (50). Plots were evaluated once prior to disease developing in treatment rows and three (2005) or four (2003 and 2004) times after disease symptoms were detected.

Ten plants were hand harvested from each treatment plot and trimmed to fresh market specifications (by removing small, outer petioles and removing the foliage $>35.6 \mathrm{~cm}$ above the base of the plant) at 90 (2003), 95 (2004), and 85 DAP (2005). Disease severity was evaluated by visually estimating the percentage of symptomatic petiole tissue on all trimmed plants. Total yield was recorded, diseased petioles were removed, and plants were weighed again to obtain disease-free yield. The yield loss percentage was expressed as the weight of diseased petioles removed (total yield minus disease-free yield) divided by the total yield. The methods of disease assessment used in this study conform with the methods suggested by Kavanagh and Ryan (21).

Statistical analysis. Disease and yield data were analyzed using an analysis of variance (ANOVA) for a randomized complete block experiment with the Proc GLM procedure of the Statistical Analysis Sys- 
tem (version 8.0; SAS Institute, Cary, NC). The equal variance assumption was examined using Levene's Robust test (35). All data were analyzed separately by year because the equal variance assumption between years usually was not met. Normality was examined using the residuals from each ANOVA and Proc Univariate procedure of SAS, and all data were square-root transformed to meet the normality assumption. The treatments in this experiment represent a two (fungicide program) by six (application program) factorial experiment with an additional untreated control treatment. Significant treatment differences were examined further using the following four linear contrasts to compare the treatments: (i) the difference between the untreated control and the average of fungicide treatments, (ii) differences among application programs across fungicide programs (main effect of application program), (iii) the difference between fungicide programs across application programs (main effect of fungicide program), and (iv) the interac-

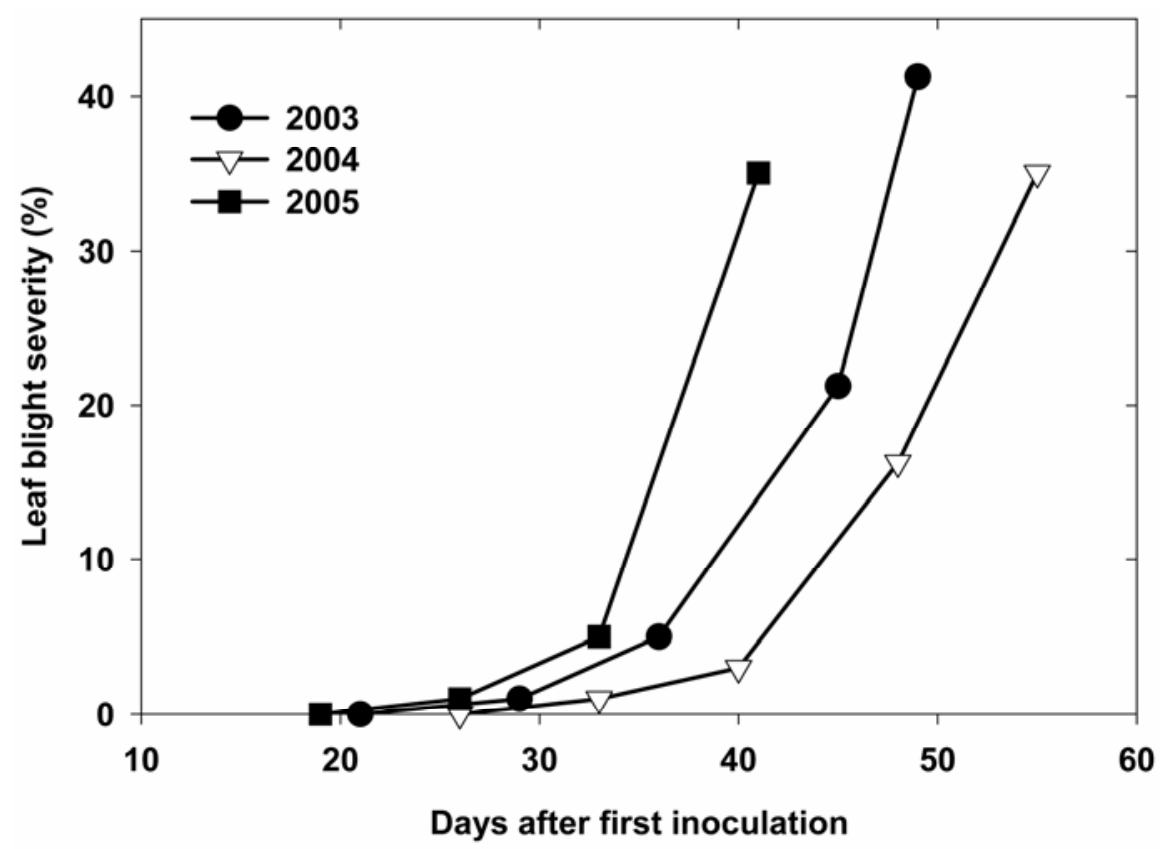

Fig. 1. Leaf blight severity of untreated 'Dutchess' celery plants when adjacent buffer row plants were inoculated with Septoria apiicola at approximately 6 and 7 weeks after transplanting in 2003 to 2005. tion between application program and fungicide program. Differences among means for any significant effect, giving priority to interaction effects, were examined using Tukey's Studentized Range test (49).

\section{RESULTS}

Environmental conditions were favorable for S. apiicola establishment and dissemination during each year of this study but were particularly favorable in 2003, when the rainfall and irrigation total was highest. Rainfall and irrigation totaled $21.9,16.3$, and $16.5 \mathrm{~cm}$ from the day after the first inoculation (DAFI) until harvest in 2003, 2004, and 2005, respectively. During the same time period, the average leaf wetness period ranged from 12.7 to 14.2 $\mathrm{h} /$ day and extended periods of leaf wetness $(\geq 12 \mathrm{~h})$ occurred on $62 \%$ (2003), $78 \%$ (2004), and $85 \%$ (2005) of the days. Mean temperatures recorded in the crop canopy were similar in $2003\left(19.3^{\circ} \mathrm{C}\right)$ and 2004 $\left(19.1^{\circ} \mathrm{C}\right)$ but were slightly warmer in 2005 $\left(22.2^{\circ} \mathrm{C}\right)$.

In each year of the study, late blight symptoms were observed on the leaves of inoculated plants 12 to 15 DAFI. S. apiicola spread to treatment rows and symptoms were detected 26 to 31 DAFI on untreated plants. Leaf blight severity on the untreated plants was $\leq 5 \%$ each year at 33 to 40 DAFI and was $35 \%$ (2004 and 2005) to $41 \%$ (2003) at the final evaluation (Fig. 1). Untreated plants trimmed to fresh market specifications had severe late blight symptoms on petioles (>38\%) (Table 1), which required additional trimming and resulted in a yield loss of 54 to $69 \%$ (Table 2). Untreated plants were not marketable

Table 1. Effects of application programs and fungicides on leaf and petiole blight severity resulting from Septoria apiicola on 'Dutchess' celery during 2003 to $2005^{\mathrm{w}}$

\begin{tabular}{|c|c|c|c|c|c|c|}
\hline \multirow[b]{2}{*}{ Treatment main effect } & \multicolumn{3}{|c|}{ Leaf blight severity (\%) } & \multicolumn{3}{|c|}{ Petiole blight severity (\%) } \\
\hline & 2003 & 2004 & 2005 & 2003 & 2004 & 2005 \\
\hline Untreated control $^{\mathrm{x}}$ & 41.3 & 35.0 & 35.0 & 51.3 & 42.5 & 38.8 \\
\hline \multicolumn{7}{|l|}{ Application program ${ }^{y}$} \\
\hline 7-day & 0.5 & $0.2 \mathrm{a}$ & $1.2 \mathrm{a}$ & $0.0 \mathrm{a}$ & $0.0 \mathrm{a}$ & $0.6 \mathrm{a}$ \\
\hline Septoria predictor & 0.7 & $0.1 \mathrm{a}$ & $1.4 \mathrm{a}$ & $0.0 \mathrm{a}$ & $0.0 \mathrm{a}$ & $0.6 \mathrm{a}$ \\
\hline Cercospora predictor & 2.2 & $0.3 \mathrm{a}$ & $0.9 \mathrm{a}$ & $0.7 \mathrm{a}$ & $0.0 \mathrm{a}$ & $0.5 \mathrm{a}$ \\
\hline TOM-CAST 10-DSV & 1.0 & $0.6 \mathrm{a}$ & $0.6 \mathrm{a}$ & $0.5 \mathrm{a}$ & $0.3 \mathrm{ab}$ & $0.7 \mathrm{a}$ \\
\hline TOM-CAST 15-DSV & 4.6 & $0.5 \mathrm{a}$ & $1.8 \mathrm{a}$ & $5.8 \mathrm{~b}$ & $0.2 \mathrm{a}$ & $2.6 \mathrm{a}$ \\
\hline TOM-CAST 20-DSV & 19.7 & $1.0 \mathrm{a}$ & $3.8 \mathrm{~b}$ & $16.5 \mathrm{c}$ & $0.7 \mathrm{~b}$ & $6.5 \mathrm{~b}$ \\
\hline \multicolumn{7}{|l|}{ Fungicide program ${ }^{\mathrm{z}}$} \\
\hline Chlorothalonil & 3.9 & $0.5 \mathrm{a}$ & $1.7 \mathrm{a}$ & $3.3 \mathrm{~b}$ & $0.3 \mathrm{a}$ & $1.7 \mathrm{a}$ \\
\hline Azoxystrobin/chlorothalonil & 3.0 & $0.4 \mathrm{a}$ & $1.4 \mathrm{a}$ & $1.9 \mathrm{a}$ & $0.1 \mathrm{a}$ & $1.5 \mathrm{a}$ \\
\hline \multicolumn{7}{|l|}{$P$ value source } \\
\hline Treatment & $<0.0001$ & $<0.0001$ & $<0.0001$ & $<0.0001$ & $<0.0001$ & $<0.0001$ \\
\hline Untreated vs. average treated & $<0.0001$ & $<0.0001$ & $<0.0001$ & $<0.0001$ & $<0.0001$ & $<0.0001$ \\
\hline Application program & $<0.0001$ & 0.0503 & $<0.0001$ & $<0.0001$ & 0.0011 & $<0.0001$ \\
\hline Fungicide program & 0.0687 & 0.4431 & 0.3070 & 0.0270 & 0.2540 & 0.7733 \\
\hline Application-fungicide interaction & 0.0008 & 0.5832 & 0.0643 & 0.0814 & 0.6802 & 0.0504 \\
\hline
\end{tabular}

${ }^{w}$ Chlorothalonil (1.7 kg a.i./ha) was applied exclusively or in alternation with azoxystrobin $(0.17 \mathrm{~kg}$ a.i./ha) where azoxystrobin was applied first. Both fungicide programs were tested with each application program. Means within a column for each treatment main effect followed by the same letter are not significantly different according to Tukey's Studentized Range test $(P \leq 0.05)$. Mean separation results are not presented for main effects when the application-fungicide interaction was significant.

${ }^{x}$ Untreated control data are shown for comparison purposes only and are not included in the statistical analyses for main effects or the interaction.

y Application program data $(n=8 /$ mean $)$ averaged across fungicide programs; DSV $=$ disease severity values.

z Fungicide program data $(n=24 /$ mean $)$ averaged across application programs. 
for fresh market use because fewer than four small, healthy petioles remained after blighted petioles were removed.

Fungicide-treated plants had significantly lower levels of disease and yield loss compared with untreated plants (Tables 1 and 2). Fungicide applications limited leaf blight severity to $<22 \%$ (2003) or $\leq 5 \%$ (2004 and 2005) and petiole blight severity to $<23 \%$ (2003) or $\leq 10 \%$ (2004 and 2005) (data not shown). When averaged across fungicide programs, similar control of petiole blight was provided by the following application programs during 2003: 7-day interval; Septoria predictor; Cercospora predictor; and TOM-CAST 10DSV predictor (Table 1). Only the 7-day interval and the Septoria predictor completely prevented yield loss (Table 2). The TOM-CAST 10-DSV and Cercospora predictors were comparable in limiting yield loss to $<3 \%$, but only the TOMCAST 10-DSV predictor was comparable to the 7-day interval. Applying fungicides according to the TOM-CAST 15- or 20DSV predictors resulted in significantly higher yield loss when compared with all other application programs (Table 2).

Across application programs, azoxystrobin/chlorothalonil resulted in similar levels of disease severity and yield loss compared with chlorothalonil (Tables 1 and 2). An exception was noted in 2003, when significant differences were detected under high disease pressure: azoxystrobin/chlorothalonil significantly reduced petiole blight severity (Table 1) and yield loss (Table 2) compared with chlorothalonil.

A significant interaction between application program and fungicide occurred for leaf blight severity in 2003, indicating that the most effective program was dependent on the fungicide (Table 1). The 7-day interval, Septoria predictor, Cercospora predictor, and TOM-CAST 10-DSV predictor were equally effective in limiting leaf blight to $<2 \%$ when chlorothalonil was applied (Table 3). Although the TOMCAST 15-DSV predictor was less effective than these programs, it resulted in significantly lower leaf blight than the TOMCAST 20-DSV predictor. When azoxystrobin/chlorothalonil was used, the 7-day interval, Septoria predictor, and TOMCAST 10-DSV predictor significantly reduced leaf blight $(\leq 1 \%)$ compared with the Cercospora predictor. The TOM-CAST 15-DSV predictor significantly reduced leaf blight compared with the TOM-CAST 20-DSV predictor and provided control similar to the Septoria, Cercospora, and TOM-CAST 10-DSV predictors when azoxystrobin/chlorothalonil was used (Table 3 ).

Under moderate disease pressure in 2004 and 2005, all disease predictors except TOM-CAST 20-DSV limited petiole blight to levels similar to the 7-day interval when averaged across fungicide programs
(Table 1). In 2005, the TOM-CAST 20DSV predictor had a significantly higher level of leaf blight than the 7-day interval (Table 1). Leaf blight severity did not differ significantly among application programs in 2004 (Table 1), but differences in yield loss occurred (Table 2). Yield loss was significantly higher when fungicides were applied according to the TOM-CAST 20-DSV predictor compared with all other application programs (Table 2).

In 2005, a significant interaction between the application program and fungicide was detected in the analysis of yield loss (Table 2). The Septoria, TOM-CAST 15-DSV, and TOM-CAST 20-DSV predictors resulted in yield losses that were statistically similar and significantly higher compared with the other application programs when chlorothalonil was applied exclusively (Table 3). All application programs were equally effective in limiting yield loss when azoxystrobin/chlorothalonil was used, with the exception of the TOM-CAST 20-DSV predictor (Table 3).

Significant interactions between application program and fungicide indicated that fungicides performed differently de-

Table 2. Effects of application programs and fungicides on yield loss resulting from Septoria apiicola on 'Dutchess' celery during 2003 to $2005^{\mathrm{w}}$

\begin{tabular}{lccc}
\hline & \multicolumn{3}{c}{ Yield loss $(\boldsymbol{\%})$} \\
\cline { 2 - 4 } Treatment main effect & $\mathbf{2 0 0 3}$ & $\mathbf{2 0 0 4}$ & $\mathbf{2 0 0 5}$ \\
\hline Untreated control $^{\mathrm{x}}$ & 54.9 & 69.1 & 63.7 \\
Application program $^{\mathrm{y}}$ & & & \\
7-day & $0.0 \mathrm{a}$ & $0.0 \mathrm{a}$ & 1.0 \\
Septoria predictor & $0.0 \mathrm{a}$ & $0.0 \mathrm{a}$ & 2.6 \\
Cercospora predictor & $2.9 \mathrm{~b}$ & $0.0 \mathrm{a}$ & 0.9 \\
TOM-CAST 10-DSV & $1.5 \mathrm{ab}$ & $0.6 \mathrm{a}$ & 0.8 \\
TOM-CAST 15-DSV & $8.4 \mathrm{c}$ & $0.3 \mathrm{a}$ & 7.0 \\
TOM-CAST 20-DSV & $32.5 \mathrm{~d}$ & $2.5 \mathrm{~b}$ & 15.6 \\
Fungicide program & & & \\
Chlorothalonil & $6.8 \mathrm{~b}$ & $0.7 \mathrm{a}$ & 3.9 \\
Azoxystrobin/chlorothalonil & $3.1 \mathrm{a}$ & $0.3 \mathrm{a}$ & 3.4 \\
$P$ value source & & & \\
Treatment & $<0.0001$ & $<0.0001$ & $<0.0001$ \\
Untreated vs. average treated & $<0.0001$ & $<0.0001$ & $<0.0001$ \\
Application program & $<0.0001$ & $<0.0001$ & $<0.0001$ \\
Fungicide program & 0.0004 & 0.1215 & 0.5918 \\
Application-fungicide interaction & 0.0747 & 0.6516 & 0.0003 \\
\hline
\end{tabular}

${ }^{w}$ Chlorothalonil (1.7 kg a.i./ha) was applied exclusively or in alternation with azoxystrobin $(0.17 \mathrm{~kg}$ a.i./ha) where azoxystrobin was applied first. Both fungicide programs were tested with each application program. Means within a column for each treatment main effect followed by the same letter are not significantly different according to Tukey's Studentized Range test $(P \leq 0.05)$. Mean separation results are not presented for main effects when the application-fungicide interaction was significant.

${ }^{x}$ Untreated control data are shown for comparison purposes only and are not included in the statistical analyses for main effects or the interaction.

${ }^{y}$ Application program data $(n=8 /$ mean $)$ averaged across fungicide programs; DSV $=$ disease severity values.

${ }^{\mathrm{z}}$ Fungicide program data $(n=24 /$ mean $)$ averaged across application programs.

Table 3. Interaction of application programs and fungicides on control of Septoria apiicola on 'Dutchess' celery in 2003 and 2005

\begin{tabular}{|c|c|c|}
\hline \multirow[b]{2}{*}{ Assessment (year), programz } & \multicolumn{2}{|c|}{ Fungicide program ${ }^{y}$} \\
\hline & Chlorothalonil & Azoxystrobin/chlorothalonil \\
\hline \multicolumn{3}{|l|}{ Leaf blight severity (\%) (2003) } \\
\hline 7-day & $0.7 \mathrm{a} \mathrm{B}$ & $0.2 \mathrm{a} \mathrm{A}$ \\
\hline Septoria predictor & $1.0 \mathrm{a} \mathrm{B}$ & $0.5 \mathrm{ab} \mathrm{A}$ \\
\hline Cercospora predictor & 1.8 a A & 2.7 c B \\
\hline TOM-CAST 10-DSV & $1.0 \mathrm{a} \mathrm{A}$ & $1.0 \mathrm{ab} \mathrm{A}$ \\
\hline TOM-CAST 15-DSV & $8.3 \mathrm{~b} \mathrm{~B}$ & $1.8 \mathrm{bc} \mathrm{A}$ \\
\hline TOM-CAST 20-DSV & $18.3 \mathrm{c} \mathrm{A}$ & $21.2 \mathrm{~d} \mathrm{~B}$ \\
\hline \multicolumn{3}{|l|}{ Yield loss (\%) (2005) } \\
\hline 7-day & $1.3 \mathrm{a} \mathrm{A}$ & 0.8 a A \\
\hline Septoria predictor & $6.1 \mathrm{~b} \mathrm{~B}$ & 0.3 a A \\
\hline Cercospora predictor & 0.2 a A & $1.8 \mathrm{a} \mathrm{B}$ \\
\hline TOM-CAST 10-DSV & 0.9 a A & 0.7 a A \\
\hline TOM-CAST 15-DSV & $12.6 \mathrm{~b} \mathrm{~B}$ & 2.9 a A \\
\hline TOM-CAST 20-DSV & $8.1 \mathrm{~b} \mathrm{~A}$ & $25.5 \mathrm{~b} \mathrm{~B}$ \\
\hline
\end{tabular}

${ }^{y}$ Chlorothalonil (1.7 kg a.i./ha) was applied exclusively or in alternation with azoxystrobin $(0.17 \mathrm{~kg}$ a.i./ha) where azoxystrobin was applied first. Means under each disease assessment-year combination in the same column (fungicide program) followed by the same lowercase letter and means in the same row (application program) followed by the same uppercase letter are not significantly different according to Tukey's Studentized Range test $(P \leq 0.05)$.

${ }^{\mathrm{z}}$ Disease assessment and application program; DSV $=$ disease severity values. 
pending on the application program. Frequently, azoxystrobin/chlorothalonil outperformed chlorothalonil under high disease pressure in 2003, with two exceptions (Table 3). Chlorothalonil applied according to the Cercospora or TOM-CAST 20DSV predictors was significantly more effective in limiting leaf blight compared with azoxystrobin/chlorothalonil (Table 3). Similar results were noted in the analysis of yield loss in 2005. When chlorothalonil or azoxystrobin/chlorothalonil was applied at 7-day intervals in 2005, there was no significant difference in yield losses. Fungicides did not differ significantly in leaf blight severity (2003) or yield loss (2005) when applied according to the TOMCAST 10-DSV predictor (Table 3).

Overall, disease predictors increased the average number of days between sprays compared with the 7-day interval. Fungicides were applied as frequently as every 7 days for the Septoria and Cercospora predictors, which is the minimum interval specified by these programs. When environmental conditions did not favor disease, a maximum application interval of 17 days occurred for the Septoria and Cercospora predictors (data not shown). The TOMCAST predictor required fungicide applications every 4 to 21 days (10-DSV), every 7 to 20 days (15-DSV), or every 11 to 28 days (20-DSV) (data not shown).

The TOM-CAST 10-DSV predictor required either the same number or up to five fewer sprays compared with the 7-day program and always resulted in equivalent disease control regardless of fungicide. The Septoria and Cercospora predictors frequently provided equivalent disease control compared with the 7-day interval and required up to two and five fewer sprays, respectively (Table 4). The TOMCAST 15-DSV predictor required three to seven fewer sprays than the 7-day interval and often provided similar control under moderate disease levels in 2004 and 2005 but not when disease was severe in 2003. The TOM-CAST 20-DSV predictor required as many as nine fewer sprays compared with the 7-day interval, but equivalent disease control was not achieved regardless of fungicide. The 7-day interval often was the most costly because it re- quired the most fungicide applications. Disease predictors which required two to seven fewer sprays than the 7-day interval reduced fungicides costs by $\$ 56$ to $\$ 196 /$ ha with chlorothalonil and $\$ 81$ to $\$ 296$ with azoxystrobin/chlorothalonil, respectively (Table 4).

\section{DISCUSSION}

Consumers demand blemish-free celery; therefore, a disease management program that requires fewer fungicide applications than the standard program must not compromise disease control. Failure of a disease predictor to limit disease in celery has significant economic consequences because the crop value is relatively high and the plant parts affected by S. apiicola are the marketable portions of the crop. In Michigan, the TOM-CAST system is used predominantly by producers of carrot and asparagus (34) that are valued at $\$ 3,424$ and $\$ 2,420 /$ ha, respectively (53). In contrast, the value of Michigan celery grown for processing and fresh market is six- to eightfold higher, at $\$ 20,431 /$ ha (53). TOMCAST is used to manage diseases of carrot and asparagus that occur on plant parts that are not marketed or consumed. TOMCAST is used to manage foliar blight on carrot leaves and petioles $(13,46)$, plant parts which supply photosynthetic energy to the edible root and must be healthy to withstand the pull of mechanical harvesters. In asparagus, TOM-CAST is used to manage purple spot on the fern after the edible spears are harvested (32). In celery, management programs which allow $S$. apiicola to infect the marketable portion of the crop are unacceptable.

The greatest disease severity was observed in 2003, when the relatively high amount of rainfall and irrigation favored dissemination and infection by $S$. apiicola $(6,47)$. Parker et al. (37) reported a linear relationship between rainfall, expressed as cumulative rainfall and cumulative hours with rain, and Septoria leaf spot severity (incited by $S$. lycopersici) on tomato foliage. In our trials, differences in disease severity among years likely impacted the efficacy of some of the fungicide treatments. For example, our 2003 results indicate that the TOM-CAST 15-DSV predic-

Table 4. Number of fungicide applications and cost of fungicides applied according to different application programs for control of Septoria apiicola during 2003 to 2005

\begin{tabular}{lccr}
\hline & \multicolumn{3}{c}{$\begin{array}{l}\text { No. of fungicide sprays (chlorothalonil cost [\$/ha]) } \\
\text { (azoxystrobin alternate chlorothalonil cost }[\mathbf{\$ h a}]]^{\mathbf{y}}\end{array}$} \\
\cline { 2 - 4 } Application program $^{\mathbf{z}}$ & $\mathbf{2 0 0 3}$ & $\mathbf{2 0 0 4}$ & \multicolumn{1}{c}{$\mathbf{2 0 0 5}$} \\
\hline 7-day & $12(336)(486)$ & $13(364)(539)$ & $11(308)(458)$ \\
Septoria predictor & $10(280)(405)$ & $11(308)(458)$ & $10(280)(405)$ \\
Cercospora predictor & $7(196)(296)$ & $10(280)(405)$ & $9(252)(377)$ \\
TOM-CAST 10-DSV & $8(224)(324)$ & $8(224)(324)$ & $11(308)(458)$ \\
TOM-CAST 15-DSV & $5(140)(215)$ & $6(168)(243)$ & $8(224)(324)$ \\
TOM-CAST 20-DSV & $4(112)(162)$ & $4(112)(162)$ & $6(168)(243)$ \\
\hline
\end{tabular}

${ }^{\mathrm{y}}$ The cost of fungicide applied was calculated using estimated costs of chlorothalonil (\$28/ha) and azoxystrobin (\$53/ha) per application.

${ }^{\mathrm{z}} \mathrm{DSV}=$ disease severity values. tor was less effective when compared with the 7-day interval when disease pressure was high. However, differences in disease control were not detected when TOMCAST 15-DSV was tested under lower disease pressure in 2004 and 2005, especially when azoxystrobin was included in the spray program. Incorporating rainfall and irrigation parameters might be beneficial to the TOM-CAST predictor for managing diseases incited by Septoria spp. as others have recommended $(18,36,37)$. Refining the TOM-CAST predictor to include these parameters could bolster the predictor for use in high-risk crops, such as celery.

Our inoculated field plots may have had higher levels of $S$. apiicola inocula than the levels that typically occur in commercial celery fields. Even the 7-day interval did not entirely prevent disease development. Under conditions of naturally occurring $S$. lycopersici inoculum, the TOMCAST 20-DSV predictor provided equivalent disease control on tomato compared with the 7-day interval, with five to six fewer applications (33). Perhaps the TOMCAST 15-DSV predictor would be acceptable under natural conditions in commercial celery fields where the inoculum load is limited by cultural control measures, including hot-water-treated seed (31) and crop rotation. However, due to the uneven distribution of late blight under natural conditions, artificial inoculation is recommended when conducting fungicide efficacy studies with $S$. apiicola (27). When the Septoria predictor was first tested in the early 1990s, S. apiicola inoculum was applied once to the experimental plots (24). In our study, we followed the recommendation of Lacy et al. (26) and inoculated the buffer rows twice to ensure adequate infection. The higher inoculum load in our experimental plots may explain why the Septoria predictor was less effective in limiting yield loss than the 7-day interval when chlorothalonil alone was applied in 2005.

In Florida, the TOM-CAST 15-DSV predictor resulted in significantly higher levels of $C$. apii damage on celery and often resulted in lower marketable yields than the weekly interval $(42,43,45)$. However, the TOM-CAST 15-DSV predictor required only two to four fungicide sprays compared with the weekly interval, which required 11 to 13 sprays $(42,43,45)$. Under the environmental conditions of our study, the TOM-CAST 15-DSV predictor required a minimum of six sprays and provided control similar to the 7-day interval in 2004 and 2005. In Canada, Trueman et al. (52) recently evaluated the TOM-CAST 20-DSV predictor for controlling late blight of celery and determined that it was not as effective as the 7-day interval. Although our results with the TOM-CAST 20-DSV predictor agree with those of Trueman et al. (52), the fungicide pro- 
grams used in our study differ greatly from those tested in Canada. Trueman et al. (52) applied copper hydroxide in alternation with either chlorothalonil or a new fungicide that currently is not registered for use on celery. Michigan celery growers often tank-mix copper hydroxide with chlorothalonil in their disease control programs because copper hydroxide limits bacterial leaf spot (12) and improves early blight control compared with chlorothalonil alone (7). Reports from Michigan $(1,11,19)$ and California $(2,38)$ indicate that copperbased fungicides provide little, if any, protection from $S$. apiicola when used alone. Although copper-based fungicides were not tested with disease predictors under the experimental conditions of our study, we are reluctant to recommend copper-based fungicides for use with disease predictors in Michigan due to their limited efficacy against $S$. apiicola.

Overall, azoxystrobin/chlorothalonil was more effective than chlorothalonil in limiting petiole blight and yield loss under high disease pressure in 2003. Also, the alternating program was more effective than chlorothalonil alone when applied every 7 days in 2003 or applied according to the Septoria or TOM-CAST 15 DSV predictors in 2003 and 2005. Raid (41) also obtained significantly better control of $S$. apiicola and higher yields when azoxystrobin was applied in alternation with chlorothalonil compared with chlorothalonil only. The benefit of including azoxystrobin in the spray program likely can be attributed to the systemic property, translaminar movement (3) and, perhaps, longer residual activity of this fungicide.

An unexpected outcome in our study was that chlorothalonil resulted in significantly lower levels of leaf blight (2003) and yield loss (2005) than azoxystrobin/chlorothalonil when applied according to the Cercospora and TOMCAST 20-DSV predictors. Potential factors that may have contributed to this outcome could be the use of robust inoculum loads and lowest labeled fungicide rates. These factors may have selected for $S$. apiicola strains with reduced sensitivity to azoxystrobin. Resistance in $S$. tritici to azoxystrobin is conferred by an amino acid substitution of glycine with alanine at position 143 on the cytochrome $b$ gene (17) or by alternative respiration; however, the latter mechanism has no effect on disease control in vivo (56). Similar evidence has not been reported for $S$. apiicola, nor have baseline sensitivities of $S$. apiicola been established for strobilurin fungicides (including azoxystrobin and trifloxystrobin, which are both registered for use on celery in the United States). Whether a target site mutation or alternative respiration occurred in S. apiicola in our study is unknown but appears unlikely because the inferior control provided by azoxystrobin/chlorothalonil was evident only in plots treated according to the Cercospora and TOM-CAST 20-DSV predictors. Furthermore, spray programs that included azoxystrobin were among the most efficacious in fungicide efficacy trials simultaneously conducted and located adjacent to the experimental plots of the present study (9-11). Nevertheless, the Cercospora and TOM-CAST 20-DSV predictors provided inconsistent and unacceptable control, respectively, compared with the 7-day interval.

The TOM-CAST 10-DSV predictor was the only disease predictor that consistently provided disease control comparable to the 7-day interval when using either chlorothalonil or azoxystrobin/chlorothalonil. This program required up to five fewer applications than the 7-day program, while reducing fungicide costs up to $\$ 215 /$ ha. The use of a 7-day minimum reapplication interval, that is required with other disease predictors $(24,51)$, is a further adjustment to the TOM-CAST predictor that may improve the usefulness of this program for celery growers. For instance, the TOM-CAST 10DSV predictor occasionally required applications at 4- to 5-day intervals, although this did not provide additional disease control benefits compared with the 7-day interval. Furthermore, chlorothalonil cannot be used more frequently than every 7 days. As new fungicides are developed for celery, these products should be tested in conjunction with disease predictors to verify their efficacy in management program that require fewer overall sprays. The environmental conditions in Michigan differ from those in other important celeryproducing areas in the United States, such as California and Florida; further validation in other areas is needed. Implementation of disease predictors that reduce fungicide inputs for late blight management in celery likely will benefit growers, consumers, and the environment.

\section{ACKNOWLEDGMENTS}

This work was funded by the United States Department of Agriculture Cooperative State Research, Education, and Extension Service, Risk Avoidance and Mitigation Program, Project Award no. 2002-51101-01908, "A strategy to advance IPM for celery growers in Michigan, California, and Florida;" American Farmland Trust and the Environmental Protection Agency, project Ecoindicators 2003-2004, "Advancing IPM for celery growers in Michigan, California, and Florida;" and Project GREEEN (a cooperative effort by Michigan plantbased commodities and businesses with Michigan State University Extension, the Michigan Agricultural Experiment Station, and the Michigan Department of Agriculture) project GR00-076, "Using resistance and reduced risk fungicides to manage Fusarium yellows and foliar diseases in celery." We thank K. L. Pernezny (University of Florida, Everglades Research and Education Center, Belle Glade) for reviewing an earlier version of this manuscript, R. N. Raid (University of Florida, Everglades Research and Education Center, Belle Glade) and S. T. Koike (University of California Cooperative Extension, Salinas) for helpful discussion on this project, and R. H. Podolsky (Medical College of Georgia, Augusta) for statistical advice.

\section{LITERATURE CITED}

1. Anonymous. 2002. Pest management in the future: a strategic plan for the Michigan celery industry. USDA Pest Management Centers, Pest Management Strategic Plans. Online publication.

2. Anonymous. 2004. A pest management strategic plan for California celery production. USDA Pest Management Centers, Pest Management Strategic Plans. Online publication.

3. Bartlett, D. W., Clough, J. M., Godwin, J. R., Hall, A. A., Hamer, M., and Parr-Dobrzanski, B. 2002. The strobilurin fungicides. Pest Manage. Sci. 58:649-662.

4. Berger, R. D. 1969. A celery early blight spray program based on disease forecasting. Proc. Fla. State Hortic. Soc. 82:107-111.

5. Berger, R. D. 1969. Forecasting Cercospora blight of celery in Florida. (Abstr.) Phytopathology 59:1018.

6. Berger, R. D. 1970. Epiphytology of celery late blight. Proc. Fla. State Hortic. Soc 83:208-212.

7. Berger, R. D. 1973. Disease progress of Cercospora apii resistant to benomyl. Plant Dis. Rep. 57:837-840.

8. Bird, G., Bishop, B., Grafius, E., Hausbeck, M., Jess, L. J., Kirk, W., and Pett, W. 2006. Insect, disease and nematode control for commercial vegetables. Mich. State Univ. Ext. Bull. 312.

9. Bounds, R. S., and Hausbeck, M. K. 2004. Evaluation of fungicides and biopesticides for managing late blight of celery, 2003. Fungic. Nematicide Tests 59:V079.

10. Bounds, R. S., and Hausbeck, M. K. 2005 Evaluation of fungicides for managing late blight of celery, 2004. Fungic. Nematicide Tests 60:V009.

11. Bounds, R. S., and Hausbeck, M. K. 2006. Evaluation of fungicides for managing late blight of celery, 2005. Fungic. Nematicide Tests 61:V121.

12. Bounds, R. S., and Hausbeck, M. K. 2006 Evaluation of products for managing bacterial leaf spot of celery, 2005. Fungic. Nematicide Tests 61:V122.

13. Bounds, R. S., Hausbeck, M. K., and Podolsky, R. H. 2006. Comparing disease forecasters for timing fungicide sprays to control foliar blight on carrot. Plant Dis. 90:264-268.

14. Cochran, L. C. 1932. A study of two Septoria leaf spots of celery. Phytopathology 22:791812.

15. Coons, G. H., and Levin, E. 1916. The Septoria leaf spot disease of celery or celery blight. Mich. Agric. Exp. Stn. Bull. 77.

16. Gabrielson, R. L., and Grogan, R. G. 1964 The celery late blight organism Septoria apiicola. Phytopathology 54:1251-1257.

17. Gisi, U., Pavic, L., Stanger, C., Hugelshofer, U., and Sierotzki, H. 2005. Dynamics of Mycosphaerella graminicola populations in response to selection by different fungicides. Pages 89-101 in: Modern Fungicides and Antifungal Compounds IV. H. W. Dehne, U. Gisi, K. H. Kuck, P. E. Russell, and H. Lyr, eds. BCPC, Alton, UK.

18. Gleason, M. L., MacNab, A. A., Pitblado, R. E., Ricker, M. D., East, D. A., and Latin, R. X. 1995. Disease-warning systems for processing tomatoes in eastern North America: are we there yet? Plant Dis. 79:113-121.

19. Hausbeck, M. K. 2002. A new program for disease management. Proc. 2002 Great Lakes Fruit, Veg., Farm Market Expo, Education Abstracts, Celery. Online publication.

20. Hausbeck, M. K., Cortright, B. D., and Linderman, S. D. 2002. Control of foliar blights of celery using standard fungicide programs and a disease forecaster, 2000. Fungic. Nematicide Tests 57:V023.

21. Kavanagh, T., and Ryan, E. W. 1971. Methods of assessment of celery leaf spot (Septoria 
apiicola) in relation to fungicide evaluation. Ann. Appl. Biol. 68:263-270.

22. Koike, S. T. 2005. Late blight of celery: a review. Monterey County Crop Notes, September-October. Online publication.

23. Kucharek, T., and Berger, D. 2000. Early, late, and bacterial blights of celery. Univ. Fla. Ext. Publ., Plant Pathology Fact Sheet, Vegetables. Online publication.

24. Lacy, M. L. 1994. Influence of wetness periods on infection of celery by Septoria apiicola and use in timing sprays for control. Plant Dis. 78:975-979.

25. Lacy, M. L., Berger, R. D., Gilbertson, R. L., and Little, E. L. 1996. Current challenges in controlling diseases of celery. Plant Dis. 80:1084-1091.

26. Lacy, M. L., and Grafius, E. J. 1980. Disease and insect pests of celery. Mich. State Univ. Ext. Bull. E-1427.

27. Lacy, M. L., Strandberg, J. O., and Paulus, A. O. 1986. Field evaluation of fungicides for control of celery diseases. Pages 182-184 in: Methods for Evaluating Pesticides for Control of Plant Pathogens. K. D. Hickey, ed. American Phytopathological Society, St. Paul, MN.

28. Linn, M. B. 1939. Dissemination of celery blight pathogens on the clothing of farm laborers. Phytopathology 29:553-554.

29. Little, E. L., Koike, S. T., and Gilbertson, R. L. 2002. Bacterial leaf spot of celery. Pages 12-13 in: Compendium of Umbelliferous Crop Diseases. R. M. Davis and R. N. Raid, eds. American Phytopathological Society, St. Paul, MN.

30. Mathieu, D., and Kushalappa, A. C. 1993. Effects of temperature and leaf wetness duration on the infection of celery by Septoria apiicola. Phytopathology 83:1036-1040.

31. Maude, R. B. 1970. The control of Septoria on celery seed. Ann. Appl. Biol. 65:249-254.

32. Meyer, M. P., Hausbeck, M. K., and Podolsky, R. 2000. Optimal fungicide management of purple spot of asparagus and impact on yield. Plant Dis. 84:525-530.

33. Mills, D. J., Coffman, C. B., Teasdale, J. R.,
Everts, K. L., Abdul-Baki, A. A., Lydon, J., and Anderson, J. D. 2002. Foliar disease in fresh-market tomato grown in different bed strategies and fungicide spray programs. Plant Dis. 86:955-959.

34. Myers, N. 2003. TOM-CAST disease prediction network in western Michigan. Michigan State Univ., Project GREEEN, Projects and Impacts, Vegetables. Online publication.

35. Neter, J., Kutner, M. H., Nachtsheim, C. J., and Wasserman, W. 1996. Applied Linear Statistical Models. WCB/McGraw-Hill, Boston.

36. Parker, S. K., Gleason, M. L., and Nutter, F. W., Jr. 1995. Influence of rain events on spatial distribution of Septoria leaf spot of tomato. Plant Dis. 79:148-152.

37. Parker, S. K., Nutter, F. W., Jr., and Gleason, M. L. 1997. Directional spread of Septoria leaf spot in tomato rows. Plant Dis. 81:272-276.

38. Paulus, A. O., Otto, H., and Nelson, J. 1981. Combination, single, and alternate applications of fungicides for control of Septoria apiicola on celery. (Abstr.) Phytopathology 71:107.

39. Pitblado, R. E. 1992. The Development and Implementation of Tom-Cast. Ontario Ministry of Agriculture and Food, Ridgetown, Canada.

40. Raid, R. N. 2002. Evaluation of standard fungicides and SAR compounds for control of late blight on celery, 2001. Fungic. Nematicide Tests 57:V025.

41. Raid, R. N. 2002. Evaluation of fungicides for control of late blight on celery, 2001. Fungic. Nematicide Tests 57:V024.

42. Raid, R. N., and Pernezny, K. 2004. Evaluation of fungicides and two weather-based forecasting systems for management of early blight on celery, 2002. Fungic. Nematicide Tests 59:V144.

43. Raid, R. N., and Pernezny, K. 2004. Evaluation of fungicides and two weather-based forecasting systems for management of early blight on celery, 2003. Fungic. Nematicide Tests 59:V145

44. Raid, R. N., and Pernezny, K. 2006. Evaluation of fungicides for management of late blight on celery, 2004. Fungic. Nematicide Tests 61:V052.

45. Raid, R. N., Pernezny, K., Havranek, N., Saddler, B., and Sanchez, J. 2005. Evaluation of fungicides and two weather-based forecasting systems for management of early blight on celery, 2004. Fungic. Nematicide Tests 60:V111.

46. Rogers, P. M., and Stevenson, W. R. 2006 Weather-based fungicide spray programs for control of two foliar diseases on carrot cultivars differing in susceptibility. Plant Dis. 90:358-364.

47. Sheridan, J. E. 1968. Conditions for infection of celery by Septoria apiicola. Plant Dis. Rep. 52:142-145.

48. Sheridan, J. E. 1968. Conditions for germination of pycnidiospores of Septoria apiicola Speg. N. Z. J. Bot. 6:315-322.

49. Steel, R. G. D., Torrie, J. H., and Dickey, D. A 1997. Principals and Procedures of Statistics. A Biometrical Approach. McGraw-Hill, New York

50. Strandberg, J. O. 1988. Establishment of Alternaria leaf blight on carrots in controlled environments. Plant Dis. 72:522-526.

51. Sullivan, M. J., Damicone, J. P., and Payton, M. E. 2003. Development of a weather-based advisory program for scheduling fungicide applications for control of white rust of spinach. Plant Dis. 87:923-928.

52. Trueman, C. L., McDonald, M. R., McKeown, A. W. and Gossen, B. D. 2006. Evaluation of disease forecasting systems for control of Septoria late blight on celery, 2005. Fungic Nematicide Tests 61:V128.

53. USDA, National Agricultural Statistics Service. 2006. Vegetables 2005 Summary. Online publication.

54. Warncke, D., and Dahl, J. 2004. Nutrient recommendations for vegetable crops in Michigan. Mich. State Univ. Ext. Bull. 2934

55. Zandstra, B. H. 2006. Weed control guide for vegetable crops. Mich. State Univ. Ext. Bull. 433.

56. Ziogas, B. N., Baldwin, B. C., and Young, J. E. 1997. Alternative respiration: a biochemical mechanism of resistance to azoxystrobin (ICIA 5504) in Septoria tritici. Pestic. Sci. 50:28-34. 